\title{
Üniversite Öğrencilerinin Katılım Bankacılığına Yönelik Bilgi, Algı ve Farkındalık Düzeyleri ve Tercihlerine Etkisi
}

\section{Dr. Öğretim Üyesi Bilgehan Tekin ${ }^{1 *}$}

Gelis tarihi: 13.12 .2018

Kabul tarihi: 25.02.2019

\section{Atıf bilgisi:}

Uluslararası Bilimsel Arastırmalar Dergisi (IBAD)

Cilt: $4 \quad$ Sayı: 1

Sayfa: 135-150 Yll: 2019

Dönem: Kı̣s

This article was checked by iThenticate. Similarity Index 18\%

${ }^{1}$ Çankırı Karatekin Üniversitesi, Türkiye, btekin@karatekin.edu.tr,

ORCID ID 0000-0002-4926-3317

* Sorumlu yazar
ÖZ

Banka müşterilerinin çalıştıkları bankaları nasıl seçtikleri sorusu araştırmacılar tarafindan geçmișten günümüze sürekli olarak incelenmiștir. Bu tür soruların cevaplarının araştırılması bankaların yeni müşteriler kazanmak ve mevcut müșterileri elde tutmak için gerekli olan uygun pazarlama stratejilerini belirlemelerine yardımcı olmaktadır. Bankacılık sektöründe artan rekabet ve bankaların sunduğu hizmetlerin benzerliği, müşterilerin finansal kurum tercihlerini etkileyen temel faktörlerin belirlenmesi konusunu daha da önemli hale getirmektedir. Katılım Bankacılı̆̆ı veya İslami Finans bankacılık sektöründe alternatif finans kurumlarından biridir. Katılım Bankacılığ 1 ile kendilerini geleneksel bankacılık sistemi dışında tutan fakat aynı zamanda birikimlerinin değerlendirilmesine ve fona ihtiyaç duyan kesimler için alternatif bir seçenek sunulmaktadır. Bu çalışma, reel ve potansiyel olarak banka müşterisi, finansal sistem katılımcısı veya aktörü olarak değerlendirilebilecek üniversite öğrencilerinin katılım bankacıllı̆ 1 terim ve hizmetleri konusundaki bilgi, farkındalık ve alg1 düzeylerinin anlaşılmasını amaçlamıştır. Bu çalışmada ayrıca öğrencilerin çeşitli demografik özellikleri ile aldıkları eğitimin ve bunun yanı sıra dini hassasiyetlerinin katılım bankacılığı ile ilgili algı ve bilgi düzeylerine etkisi de incelenmiştir. Öğrenciler, belli sayıda ders kredisini tamamlamıs olanlardan ve ekonomi, finans ve bankacılık alanları ile ilgili en az 2 ders almıș olan öğrencilerden seçilmiștir. Çalışmada toplam 324 öğrenciye anket uygulaması yapılmış söz konusu anketlerden 293 tanesi analize uygun bulunmuștur. Calıșma sonucunda İslami Bankacilık ve uygulamalarının Çankırı Karatekin Üniversitesi öğrencileri arasında bilgi ve farkındalık düzeylerinin oldukça düşük olduğu gözlenmiștir. Katılım bankası tercihinde din faktörü etkili bir faktördür. Ayrıca yapışan bağımsız gruplar $t$ test sonuçlarına göre İslami bankacılığa yönelik olumlu algı ile tercih edilme düzeyi arasında pozitif bir ilișki söz konusudur.

Anahtar Kelimeler: Katılım Bankacılığı, İslami Finans, Bilgi, Algı, Farkındalık 


\title{
The Effect of University Students' Preferences, Perception and Awareness Levels on
} Participation Banking

\author{
Asst. Prof. Bilgehan Tekin ${ }^{1 *}$
}

First received: 13.12 .2018

Accepted: 25.02.2019

\section{Citation:}

Journal of the International

Scientific Research (IBAD)

Volume: $4 \quad$ Issue: 1

Pages: 134-150 Year: 2019

Session: Winter

This article was checked by iThenticate. Similarity Index 18\%

1 Cankiri Karatekin University, Turkey, btekin@karatekin.edu.tr, ORCID ID 0000-0002-4926-3317

* Corresponding Author

\begin{abstract}
The question of how bank customers choose the banks that they work with has been continuously examined by researchers from past to present. The search for answers to such questions helps banks identify the appropriate marketing strategies needed to win new customers and retain existing customers. Increasing competition in the banking sector and the similarity of the services offered by banks make it even more important to determine the key factors that affect the preferences of the customers. Participation Banking or Islamic Finance is one of the alternative financial institutions in the banking sector. With Participation Banking, an alternative option is offered for those who keep themselves out of the traditional banking system but who also need debt and to invest their funds. This study aimed to understand the level of knowledge, awareness and perception of participation banking terms and services of university students who could be evaluated as real and potentially bank customers, financial system participants or actors. This study also examined the effect of the students' perceptions and knowledge on the participation banking function, services and products in the education system of finance and banking. The students were selected from students who have completed a certain number of course credits and have taken at least 2 courses in economics, finance or banking. In the study, a total of 324 students were surveyed and 293 of them were found suitable for the analysis. Factor analysis, ANOVA analysis, independent groups $t$ test, regression analysis, correlation analysis methods were used in the study. As a result of the study, it was observed that the level of knowledge and awareness of Islamic Banking and its applications was very low among the students of Çankırı Karatekin University. Religious factor is an effective factor in the choice of participation bank. There is also a positive relationship between the positive perception of Islamic banking and the level of preference.
\end{abstract}

Keywords: Participation Banking, Islamic Finance, Knowledge, Preference, Awareness. 


\section{GİRİ̧̧}

İslam dini Müslümanların faizle işlem yapmalarını veya faizle borç alıp vermelerini yasaklar. Diğer bir deyişle İslam dini kişilerin sabit bir getiri elde etmelerini katlanılan riske ortak olmaları şartına bağlı kılmıştır (Ariff, 1988). Katılım bankacılığı veya diğer İslam ülkelerindeki ifadesi ile "İslami Bankacılık" temel anlamda Müslüman ülkelerde yaşamın her alanında İslam Hukuku ilkelerine uymakla yükümlü olan Müslüman bireylerin birikimlerinin finansal sisteme dâhil edilmesini sağlamak ve onların ihtiyaçlarını karşılamak üzere kurulmuş bir sistemdir. İslami bankacılık ile kendilerini geleneksel bankacılık sistemi dışında tutan fakat aynı zamanda birikimlerinin değerlendirilmesine ve fona ihtiyaç duyan kesimler için alternatif bir seçenek sunulmaktadır. Bununla birlikte İslami bankacılık mevcut finansal sistemi kolaylaştırmayı da amaçlamaktadır. Bu nedenle, konu ile ilgili yapılan çalışmalarda görüldüğü gibi Müslümanların yanı sıra gayrimüslimler tarafından da bu sistemin sunduğu hizmetlere karş1 olumlu tepkiler verilmekte ve ilgi gösterilmektedir (Abdullah, Sidek \& Adnan, 2012; Harun, Rashid \& Hamed, 2015).

İslami finans sistemi ilk defa 1963 yılında Mısır'da Ghamr Savings Bank'ın kurulması ile ortaya çıkmış ve daha sonra diğer İslam ülkelerinde ve Birleşik Krallık' ta uygulanmaya başlanmıştır. 1970'li yıllarda sayıları ciddi seviyelere ulaşmıştır. Türkiye'de ise ilk olarak 1983 yılında "Özel Finans Kurumları" adı altında kurumsallaşmış, 2005 yılında ise Bankacılık Kanununda yapılan düzenleme ile Türk Bankacılık Sistemine "Katılım Bankacılığı" adı altında dâhil edilmiştir (Toraman, Ata ve Bugan, 2015). Türkiye bankacıllk ve finans sistemi içerisinde şu an 3 adet özel sermayeli 2 adet ise kamu sermayeli katılım bankası faaliyette bulunmaktadır. Türkiye'de bu sektöre adımını atan ilk finansal kurum 1984 yılında Albaraka Türk olmuştur. Daha sonra 1985 yılında Faysal Finans, 1989 y1lında Kuveyt Türk, 1991 yılında Anadolu Finans, 1995 yılında İhlas Finans ve 1996 yılında Asya Finans sektöre adım atmıştır. 2005 yılında Faysal Finans ile Anadolu Finans birleşerek Türkiye Finans'ı kurmuşlardır. İhlas Finans'ın faaliyetleri ise 2001 yılında BDDK tarafindan durdurulmuştur (Özdemir ve Aslan, 2017).

Türk bankacılık sektörü Cumhuriyetin ilk yıllarında Ziraat Bankası ve az sayıdaki özel yerel banka girişimi dışında tamamen yabancı sermayenin elindeydi. İzmir'de düzenlenen İktisat Kongresi'nde alınan kararlar çerçevesinde 1924 yılında İş Bankası, 1925 yılında Sanayi ve Maadin Bankaları, 1926 yılında da Emlak ve Eytam Bankası kurularak Türkiye'de milli bankacıllk sisteminin ilk temelleri atılmıştır. 1930 yılında Atatürk'ün gerçekleştirdiği girişimler sonucunda T.C. Merkez Bankası Kanunu kabul edilmiştir. Sonraki süreçte Büyük Buhran ekonomik krizinin etkisinden kurtulmak için geliştirilen politikaların da etkisi ile bankacılık sisteminde kamu kesiminin sermayesi artmıştır. 1945-1946 yılları arasında bankalar mevduat toplamaya öncelik vermiş ve şube sayısını giderek arttırmışlardır. 1960-1980 yılları arasındaki dönemde ise bankalar yoğun bir ş̧ekilde kamu sermayeli yatırımların finansmanını sağlamıștır. Türk bankacılık sistemi 1980 ekonomik kararları ve 1989 yılında çıkarılan "Türk Parasının Kıymetini Koruma" ile ilgili düzenlemelerin ardından büyük gelişme göstermiş ancak 1991 yılındaki Körfez krizinden olumsuz etkilenmiştir. 1993 yılının sonları ve 1994 yılının başlarında döviz kurlarında yaşanan dalgalanmalar ve faiz riski ve kur riski gibi tehlikeler ortaya çıkmış ve kriz yaşanmıştır. $\mathrm{Bu}$ krizin sonucunda bazı bankalar kapanmıştır. 1999 yılındaki Asya Krizi ve 2000 ve 2001 yıllarında Türkiye' de yaşanan ekonomik krizler sonrasında ise 25 banka TMSF'ye devredilmiştir. Bu gelişmeler sonucunda bankacılık sisteminin güçlendirilmesine yönelik BDDK öncülüğünde çeşitli çalışmalar yapılmış ve BDDK'nın bankacılık sektörü üzerinde artan denetimi, yeni bankacılık kanunun oluşturulması gibi alınan önlemler sonucu Türk Bankacılık sistemini güçlendirmiştir. Bugün Türk Bankacılık Sektörü, Mevduat Bankaları (Konvansiyonel Bankacılık), Katılım Bankaları (İslami-Faizsiz Bankacılık) Kalkınma ve Yatırım Bankaları olarak dört ana başlık altında sınıflandırılabilir (Oğuz, 2016). Her sınıf altında hem kamu sermayesi hem de özel sermayeli bankaları görmek mümkündür.

Günümüzde katılım bankacılığının uygulamaya koyduğu ürünler ve hizmetler sadece İslam ülkelerinde değil tüm dünya ülkelerinde giderek daha fazla talep görmektedir. Katılım Bankaları Birliği’nin 2016 yılı raporuna göre küresel finans varlıklarının \%2' ye yakın bir bölümünü temsil eden küresel faizsiz finans toplam varlıklarının 2015 yılı sonu itibarıyla 2 trilyon ABD dolarını aşmış olduğu tahmin edilmektedir (KBB, 2016). "ICD Thomson Reuters Faizsiz Finans Gelişim Raporu-2016" da yer alan verilere göre; faizsiz finans sisteminin toplam varlıkları, \%8 büyüme kaydederek 2015 yılsonu itibarıyla 2.003 milyar ABD dolarına ulaşmıştır (TKBB, 2016). Türkiye'de 2016 yılında katılım bankalarının toplam aktifleri 
\%10,5 büyüme ile 133 milyar TL'ye ulaşmış, pazar payı ise \%4,9 olarak gerçekleşmiştir. Katılım bankalarının görece temkinli politikalarla faaliyet gösterdikleri 2016 yılında reel sektöre kullandırdıkları fonların toplamı \%7,2 artışla 84,8 milyar TL'ye ulaşmıştır. Toplanan ve kullandırılan fonların 2016 yılında sektördeki payı sırasıyla \%5,6 ve \%4,8 olmuştur. Katılım bankacıllığ sektörü, 2016 yılında net kârında \%173 gibi yüksek bir oranla artış gerçekleştirerek 1.106 milyon TL ile yılı tamamlamıştır. Buna bağlı olarak, katılım bankalarının net kardaki toplam sektör payı \%1,6'dan \%2,9'a yükselmiştir (TKBB, 2016). Faizsiz bankacılık sektöründe yıllık ortalama aktif büyümesinin en hızlı olduğu ülkeler sıralamasında ise Türkiye \%30 ile \%43 ile birinci sırada yer alan Endonezya'nın hemen ardından gelmektedir (TKBB, 2015).

Türkiye Cumhuriyeti'nin insan sermayesi oldukça fazladır ve bu insanların büyük bir çoğunluğu İslam dinine mensuptur. Ayrıca geleneksel bankacılık sektörünün hizmet ve ürünlerinden hem bireysel kullanıcılar hem de kurumsal kullanıcılar tarafindan sürekli olarak dile getirilen bir takım güven problemleri ve memnuniyetsizlikler söz konusudur. Türk bankacıllı sektörünün daralması ve Türkiye'nin ekonomik göstergelerinin her geçen gün daha iyiye gitmesi gibi gelişmeler de yaşanmaktadır. Katılım Bankacılı̆̆ının gelişmesi ve sektörün büyümesi beraberinde rekabeti de getirecek ve vatandaşların finansmana ve finansal ürünlere erişimlerini kolaylaştıracaktır. Ayrıca katılım bankacılığı sektörünün gelişmesi konvansiyonel bankacılığın da kendini daha fazla ve hızlı yenilemesini, daha kaliteli hizmet anlayışını ve rekabete ayak uydurmasını sağlayacak bir unsurdur.

Tüm bu faktörler göz önüne alındığında katılım bankacılığı sektörü açısından mevcut firsatların veya potansiyelin yeterince değerlendirilemediği ve yukarıda yer alan verilerin yeterli düzeyde olmadığı düşünülmektedir. Örneğin, Türkiye, katılım bankası sayısı bakımından şu an İran Suudi Arabistan, Bangladeş, Malezya, BAE, Kuveyt, Bahreyn, Katar, Türkiye ve Endonezya'nın bulunduğu listede son sıradadır. Yine aktif büyüklüğü açısından bakıldığında en son sırada yer alan Endonezya'nın sadece bir basamak üstündedir (TKBB, 2015). İslami bankacıllğın ülkelerdeki pazar payı açısından bakıldığında ise listede yer alan 35 ülke arasında 19. sirada olduğu görülmektedir (IFSB, 2017). Bu nedenle Türkiye'de katılım bankacılığı sisteminin geliştirilmesine ve geniş kitlelere yayılmasına yardımcı olacak çalışmaların sayısının artması, farklı ve yol gösterici çalışmaların yapılması, yeni stratejilerin ve politikaların uygulamaya konulması gerekmektedir.

Bu çalışmada örneklem olarak, Türkiye'de bankacılık sistemi ürünlerinden ve hizmetlerinden belirli ölçülerde yararlanan veya potansiyel finansal piyasa katılımcısı olarak gelecekte aktif olarak bu piyasalarda yer alması beklenen üniversite öğrencileri alınmıştır. Böylelikle lisans eğitimi alan genç nüfusun bilgi, algı ve farkındalık düzeylerinin geleceğe yönelik farklı stratejiler ve politikalar oluşturulmasında kullanılabilecektir. Aynı zamanda, gelecekte bu çalışmanın bulguları ile gelinen düzey arasında karşılaştırmalar yapılabilecektir. Bu nedenlerle bu çalışma ile aynı zamanda geleceğe yönelik bir başvuru kaynağı oluşturulması ve bu şekilde Türkiye'de katılım bankacılığı sektörüne yön verenlerin alacakları kararlara yardımcı sonuçlar ortaya konulması ve mevcut politikaların eğitimli genç nüfustaki karşılığının değerlendirilmesine imkan tanımak amaçlanmıştır.

\section{LITERATÜR TARAMASI}

Katılım Bankacılığı veya özellikle İslam ülkelerinde yaygın olarak kullanılan tanımlama ile İslami Finans, akademik alanda yapılan çok sayıda çalışmaya konu olmuştur. Konu ile ilgili yapılan ilk çalışmalardan sayılabilecek ve Erol \& El-Bdour (1989) ve Erol, Kaynak \& El-Bdour (1990) tarafından yapılan ve İslami bankacılık tercihine etki eden faktörlerin belirlenmesini konu alan çalışmaların sonuçlarına göre bireylerin İslami finans tercihi üç temel kritere dayanmaktadır. Bunlar; hızlı ve verimli hizmet sunumu, itibar ve gizliliktir. Söz konusu araştırmacılara göre dini motivasyon temel kriterlerden biri değildir.

Ahmad \& Haron (2002), Malezya'daki halka açık şirketlerin finansal işlerinden sorumlu kişilerin İslami Bankacılık algılarını araştırmışlardır. Ulaştıkları bulgulara göre Malezya'daki kurumsal firmalarda finansal karar alma yetkisine sahip olan kişilerin neredeyse yarısı İslami bankacıllk sisteminin geleneksel sisteme alternatif olarak iyi bir potansiyele sahip olduğuna inanmaktadır. İslami bankacılık ürün ve hizmet sağlayıcılarının, müşterilerini eğitmek ve ürünlerini pazarlamak için yeterince çaba göstermediğini tespit etmişlerdir. Pazarlama ve reklam faaliyetleri açısından eksiklikler 
tespit etmişler ve bunun İslami bankacılığın daha küçük pazar payına neden olduğunu belirtmişlerdir. Aynı zamanda kurumsal müşterilerin banka seçiminde dikkate aldıkları en önemli faktörün, hizmet ve ürünlerin maliyeti olduğunu bu nedenle İslami bankacılık ürünlerinin maliyetinin en azından geleneksel bankaların maliyetleri kadar hatta daha düşük olması gerektiğini belirtmektedirler.

Bley \& Kuehn (2004), üniversite öğrencilerinin geleneksel ve İslami bankacılık kavramları ve terimleri ile ilgili bilgi düzeyleri arasındaki ilişki ile din, dil ve diğer bireysel faktörlerin tercihler üzerindeki etkisini araştırmışlardır. Sonuçlar, öğrenciler arasında geleneksel bankacılık terimleri ve kavramları ile ilgili bilgi düzeyinin İslami bankacılık terminolojisinden daha yüksek olduğunu göstermiştir. Arapça dil, İslami bankacılık bilgisini arttıran bir unsur olmuştur. Eğitim düzeyi arttıkça hem geleneksel hem de İslami finans bilgisinin arttığı görülmüştür. Finans öğrencilerinin finansal sistemler hakkındaki bilgi düzeylerinin daha fazla olduğu tespit edilmiştir. Aynı zamanda dini hassasiyet ile bilgi düzeyinin, tercihleri belirleyen en önemli etken olduğu görülmüştür.

Loo (2010), Müslüman ve Müslüman olmayan bireyler arasında İslami Bankacılık konusundaki tutum ve algı farklılıklarını araştırmıştır. Sonuçlar, Müslümanların İslami Bankacılığı desteklediklerini buna karşın Müslüman olmayanların ise İslami Bankacılığı Müslümanları ilgilendiren bir bankacılık sistemi olarak gördüklerini ortaya koymuştur. Bununla birlikte İslami Bankacılığa, gayrimüslim X kuşağının, diğer kesimlere göre daha olumlu yaklaştığ 1 tespit edilmiştir.

Rustam, Bibi, Zaman, Rustam \& Haq (2011), kurumsal müşterilerin Pakistan'daki İslami bankacılık ürün ve hizmetlerine yönelik algılarını incelemişlerdir. Veriler anket yöntemi ile Pakistan'ın tam teşekküllü altı ticari bankasının kurumsal müşterisinden toplanmıştır. Sonuçlar, İslami bankacılık ürünlerinin ve hizmetlerinin Pakistan kurumsal sektöründe iyi bir potansiyele sahip olduğunu göstermiştir. Bununla birlikte kurumsal müşterilerin büyük çoğunluğunun, Pakistan'daki İslami bankacılık ürün ve hizmetleri ile ilgili sınırlı bilgiye sahip olduğu görülmüsstür. Araştırmacılara göre bunun nedeni, İslami bankaların ürün ve hizmetlerini pazarlamak için yeterince çaba göstermemeleridir. Müşterileri İslami bankacılık ürünleri ve önemi konusunda eğitmek için bir ihtiyaç vardır. Katılımcıların çoğunluğu, din ve ekonomi faktörlerini, kişilerin İslami Bankacılık tercihlerinde dikkate aldıkları 2 önemli faktör olduğunu belirtmişlerdir.

Nawi, Yazid \& Mohammed (2013) İslami Bankacılık tercihini belirleyen kriterler üzerine yaptıkları literatür araştırması sonucunda, bireylerin İslami bankacılığı tercih etmelerinin temel nedenlerini şeriata uygun olması, diğer bankaların dine aykırılığı, hizmet kalitesi ve cazibesi ve İslami bankacılığın gelişme potansiyeli olarak ifade etmişlerdir.

Demir \& Atlı (2014), katılım bankalarını tercih eden müşterilerin katılım bankacılığı hizmetlerinden elektronik iletişim kanalları ile yararlanma düzeylerini tespit etmeye yönelik yapmış oldukları çalışmada, katılım bankalarının mevduat bankalarına göre daha kuralcı ve daha güvenli bir bankacılık modeli geliştirmeye çalıştıklarını tespit etmişlerdir. Katılım Bankalarının internet bankacılığı sistemini kullanan müşteriler zaman sınırlaması olmadan birçok bankacılık işlemini gerçekleştirdiklerini; bunun, Katılım Bankalarının tercih edilmesinde önemli bir etken olduğunu belirtmişlerdir.

Toraman, Ata \& Buğan (2015), mevcut ve potansiyel banka müşterilerinin İslami bankacıllk faaliyetlerine yönelik algılarını araştırmışlardır. Çalışma sonucunda katılım bankacılığının kişiler tarafından yeterince bilinmediği ve potansiyel banka müşterilerinin İslami finans algısının çok zayıf olduğu anlaşılmıştır.

Noonari vd. (2015), üniversite öğrencilerinin İslami bankacılıkta kullanılan farklı kavram ve terimler hakkındaki algıları ile sunulan ürün ve hizmetler arasındaki ilişkiyi araştırmışlardır. Ayrıca öğrencilerin yaş, cinsiyet, çalışma alanı, ikamet yeri, genel not ortalaması ve hane halkı gelirinin İslami bankacılık konusundaki algı ve bilgilerine etkisi de incelenmiştir. Sonuçlar, kişilerin dini hassasiyetlerinin, İslami bankacıllı̆ın tercih edilmesinin en güçlü göstergesi olduğunu ortaya koymuştur. Aynı zamanda, öğrencilerin İslami bankacılık hakkında iyi bir algıya sahip oldukları; ancak bilgilerinin zayıf olduğu anlaşılmıştır. Arapça dilinin öğrencilerin İslami Bankacılık ürün ve hizmetlerinin anlaşılmasını engellediği; yaş ve gelir faktörlerinin, öğrencilerin İslami bankacılık konusundaki alg1 ve bilgileri ile pozitif bir ilişki gösterdiği belirlenmiştir. 
Özen, Şenyıldız \& Akarbulut (2016) yaptıkları çalışmada hane halklarının katılım bankaları ile ilgili algılarını ölçmek istemişlerdir. Çalışmada, Uşak ilinde 510 kişiye anket uygulaması yapılmıştır. Çalışma sonucunda bireylerin katılım bankacılığı algısının düşük olduğu görülmüş ve cinsiyet, eğitim, meslek ve gelir düzeyi gibi faktörlerin katılım bankacılığ 1 ile ilgili bilgi düzeyi üzerinde istatistiksel olarak anlamlı farklılığa neden olduğu anlaşılmıştır.

Asdullah \& Yazdifar (2016), Pakistan'da genç nüfusun (18-24 yaş) İslami Bankacılığa bakış açılarını etkileyen faktörleri araştırmışlardır. Sonuçlar, erkek ve kadın katılımcıları etkileyen faktörlerin benzer olmadığını göstermiştir. Kadınların, İslami Bankacılığın temel ilkeleri hakkında yeterli bilgi ve bilince sahip olmadığı sonucuna varılmıştır. Bunun, kadınların iş dünyasında yeteri kadar yer almamalarından kaynaklanabileceği ifade edilmiştir. Erkek katılımcılar, dini algıları, maliyet etkinliği ve hizmet kalitesi nedenleriyle İslami Bankacılık hizmetlerini tercih ettiklerini; gençler ise İslami banka tercihlerine ana etkenin dini motivasyon olduğunu belirtmişlerdir.

Ahmet, Bano \& Dawood (2017), Pakistan'ın bir eyaleti olan Belucistan'da yaptıkları araştırmada İslami bankacılığın bireyler arasındaki algı düzeyini araştırmışlardır. Sonuçlar, bireylerin, dini faktör, kişisel ilgi, kişilik, referans grupları, sosyal refahın katkısı, şeriat kuruluna olan inanç gibi farklı nedenlerle İslami bankacılık ile ilgilendiklerini göstermiştir. Yazarlar bu durumun, bireylerin İslami bankacılığın temel prensiplerini anladıkları anlamında gelmediğini de belirtmişlerdir.

Riaz, Khan \& Khan (2017), tüketicilerin Pakistan'daki İslami bankacılık ve finans konusundaki algılarını incelemişlerdir. Bulgular, Pakistan'da İslami bankacılık ve finans konusunda olumlu bir algının olduğunu ortaya koymaktadır. Farkındalık, bilgi ve dindarlık düzeyleri, İslami finans ürün ve hizmet algisı üzerinde olumlu bir etkiye sahiptir.

Anaç \& Kaya (2017), İstanbul'da faaliyet gösteren dört ayrı katılım bankasının müşterilerine anket uygulaması gerçekleştirmişlerdir. Topladıkları veriler üzerinden yaptıkları analiz sonuçlarına göre katılımcıların katılım bankası tercihlerini etkileyen en önemli faktörlerin; bankaların sahip oldukları katılım bankası ve faizsiz kurum imajları ve popülariteleridir. Diğer önemli faktörler ise sırasıyla, dini hassasiyetlerin yönlendirmesi ve banka çalışanlarının müşterilere karşı yaklaşımıdır.

\section{3. ÇALIŞMANIN YÖNTEMI}

Çalışmada veri toplanması amacıyla anket yöntemi kullanılmıştır. Çalışmada kullanılan anket daha önce Toraman, Ata ve Buğan (2015) tarafından yapılan çalışmadan alınmıştır. Ankette, öğrencilerin katılım bankacılığı ile ilgili bilgi, algı ve farkındalık düzeylerini ölçen ifadeler, katılım bankası ile çalışıp çalışmama tercihleri ve demografik özelliklerine ilişkin sorular yer almaktadır.

Çalışmada faktör analizleri, ANOVA analizi, bağımsız gruplar $t$ testi, regresyon analizi, korelasyon analizi yöntemleri kullanılmıştır. Öğrenciler, belli sayıda ders kredisini tamamlamış olan ve ekonomi, finans ve bankacılık alanları ile ilgili en az 2 ders almış olan öğrencilerden seçilmiştir. Çalışmada toplam 324 öğrenciye anket uygulaması yapılmış söz konusu anketlerden 293 tanesi analize uygun bulunmuştur.

\subsection{Veri Analizi ve Bulgular}

\subsection{1. İslami Bankacılık Algısı Ölçeğine Yönelik Tanımlayıcı Analizler}

Yapılan analize ilişkin tanımlayıcı istatistikler Tablo 1'de görülmektedir. Tablo 1 incelenirken öncelikle verilerin analizinde parametrik analiz yöntemlerinin uygulanabilmesi için ön şart olan normal dağılım tanımlayıcı istatistiklerden Çarpıklık-Basıklık değerlerine bakılarak değerlendirilmiştir. Söz konusu değerlerin $+1,5$ ile $-1,5$ aralığında veya $+2,0$ ile $-2,0$ aralığında olmaları normal dağılımı işaret etmektedir (Tabachnick \& Fidell, 2013; George \& Mallery, 2010) ${ }^{1}$. Tablo 1'den görüldüğü üzere söz konusu değerler belirtilen aralıktadır. Bu nedenle veriler normal dağılmaktadır.

\footnotetext{
${ }^{1}$ Dağılımın normal dağılıma göre daha solda (negatif yönlü) ya da sağda (pozitif yönlü) şekillenmesi yani normal dağılıma göre çarpık olması çarpıklık katsayısının negatif ya da pozitif değer alması sonucunu doğurur. Aynı şekilde dağılımın normal dağılıma göre daha dik (pozitif değer) ya da basık (negatif değer) olması basıklık katsayısının negatif ya da pozitif değer alması sonucunu doğurur. Tam normal dağılımın basıklık katsayısı "sıfır"dır (Brown, 1997; DeCarlo, 1997).
} 
Ölçeğe ilişkin tanımlayıcı istatistiklere dayalı genel bir değerlendirme yapıldığında öğrencilerin ölçekte yer alan ifadelere katılım düzeylerinin "kararsızım" seçeneğinde yoğunlaştığı belirtilebilir. Tablo 1'e göre, genel olarak öğrencilerin katılım bankacılığı konusunda değerlendirme yapabilecek bilgi ve farkındalık seviyesine sahip olmadıkları sonucuna varılabilir. Nitekim bilgi düzeyine ilişkin ifadeye katılım düzeyinin ortalamasının da kararsızım seviyesinde olduğu da görülmektedir (Tablo 1 'de yer alan 2. madde). Tablo 1'de bir başka dikkat çeken unsur "İslami bankacılıkla ilgili reklam veya ilanlarla karşılaşma sıklığınız nedir?" sorusuna verilen cevapların daha çok "Hiç karşılaşmıyorum" ile "Nadiren Karşılaşıyorum" şeklinde verildiğidir (Tablo 3'ten daha net görülebilir). Bu sonuç, katılım bankacılığı reklamlarının üniversite düzeyindeki gençler açısından yeterli düzeyde olmadığı, ilgi çekmediği, onlara hitap etmediği veya gençlere ulaşamadığı şeklinde yorumlanabilir.

Tablo 1: İslami Bankacılık Algısı Ölçeğine Yönelik Tanımlayıcı İstatistikler

\begin{tabular}{|c|c|c|c|c|c|}
\hline MADDELER & Ortalama & Medyan & Std. Sapma & Çarpıklık & Basıklık \\
\hline $\begin{array}{l}\text { İslami bankacılığg (Katılım } \\
\text { Bankacılığı) ne düzeyde } \\
\text { ulaşılabilir buluyorsunuz? }\end{array}$ & 3,14 & 3 & 0,952 & $-0,3$ & 0,058 \\
\hline $\begin{array}{c}\text { İslami bankacılıkla ilgili } \\
\text { bilgi düzeyinizi nasıll } \\
\text { değerlendirirsiniz? }\end{array}$ & 3,15 & 4 & 1,222 & $-0,525$ & $-0,925$ \\
\hline $\begin{array}{c}\text { İslami bankacılığın size } \\
\text { uygun yatırım ürünleri } \\
\text { sunduğunu düşünüyor } \\
\text { musunuz? }\end{array}$ & 3,14 & 3 & 0,754 & $-0,243$ & 0,872 \\
\hline $\begin{array}{l}\text { İslami bankacılıktaki } \\
\text { katılımcılık esasının } \\
\text { geleneksel bankacılıktan } \\
\text { daha faydalı olduğuna } \\
\text { inanıyor musunuz? }\end{array}$ & 3,18 & 3 & 0,791 & $-0,12$ & 0,943 \\
\hline $\begin{array}{c}\text { İslami bankacılık } \\
\text { sektöründe yatırım yapmak } \\
\text { sizin için ne kadar } \\
\text { önemlidir? } \\
\end{array}$ & 3,12 & 3 & 0,99 & $-0,235$ & $-0,286$ \\
\hline $\begin{array}{l}\text { Sizce İslami bir banka sizin } \\
\text { fonlarınızı ne kadar iyi } \\
\text { yönetebilir? }\end{array}$ & 3,27 & 3 & 0,905 & $-0,356$ & 0,023 \\
\hline $\begin{array}{c}\text { İslami bankacılık ve } \\
\text { geleneksel bankacılık } \\
\text { arasında bir tercih yapmak } \\
\text { durumunda kalırsanız İslami } \\
\text { bankacılığa yatırım yapmayı } \\
\text { tercih eder misiniz? }\end{array}$ & 3,29 & 3 & 1,038 & $-0,234$ & $-0,563$ \\
\hline $\begin{array}{l}\text { İslami bankacılıkla ilgili } \\
\text { reklam veya ilanlarla } \\
\text { karşılaşma sıklığınız nedir? }\end{array}$ & 2,07 & 2 & 0,932 & 0,649 & 0,083 \\
\hline $\begin{array}{l}\text { İslami bankacılığı } \\
\text { kullanırken dini açıdan ne } \\
\text { ölçüde zorunluluk } \\
\text { hissedersiniz? }\end{array}$ & 2,63 & 3 & 1,344 & 0,138 & $-1,204$ \\
\hline $\begin{array}{l}\text { İslami bankacılığı finansal } \\
\text { amaçlarım doğrultusunda } \\
\text { düşünürüm. }\end{array}$ & 3,24 & 3 & 0,974 & $-0,293$ & $-0,25$ \\
\hline $\begin{array}{c}\text { İslami bankacılık diğer } \\
\text { bankaların iyi bir }\end{array}$ & 3,32 & 3 & 0,86 & $-0,386$ & 0,462 \\
\hline
\end{tabular}


alternatifidir.

\begin{tabular}{|c|c|c|c|c|c|}
\hline $\begin{array}{c}\text { Genel olarak finansal } \\
\text { sistemde faiz esası geçerli } \\
\text { olduğu için İslami } \\
\text { bankacılık gerçekçi değildir. }\end{array}$ & 3,01 & 3 & 1,014 & 0,026 & $-0,449$ \\
\hline $\begin{array}{c}\text { İslami bankacılık kredi alma } \\
\text { konusunda geleneksel } \\
\text { bankacılıktan daha iyi } \\
\text { firsatlar sunar. }\end{array}$ & 3,12 & 3 & 0,829 & $-0,045$ & 0,423 \\
\hline $\begin{array}{c}\text { İslami kurallara daha uygun } \\
\text { oldukları için İslami } \\
\text { bankacılığı daha fazla tercih } \\
\text { ederim }\end{array}$ & 3,24 & 3 & 0,949 & $-0,341$ & $-0,103$ \\
\hline $\begin{array}{l}\text { İslami bankacılık çok geniş } \\
\text { bir yelpazede yatırım } \\
\text { fırsatları sunmaktadır. }\end{array}$ & 2,96 & 3 & 0,723 & $-0,272$ & 1,619 \\
\hline
\end{tabular}

\subsubsection{Frekans Analizleri}

Çalışmanın frekans analizi bölümünde öncelikle katılımcıların demografik ve diğer bilgilerine yönelik analiz gerçekleştirilmiştir. Tablo 2' de sonuçlarına yer verilen analize göre katılımcıların \%64,8' i erkek ve $\% 35,2$ si kadınlardan oluşmaktadır. Katılımcıların \%25,3' ü 17-20 yaş aralığında ve \%73,7' si 21-25 yaş aralığındadır. Katılımcıların \%25,9' u işletme bölümü, \%15'i Bankacılık ve Finans bölümü, \%27,6'sı ise Bankacılık ve Sigortacılık bölümü öğrencisidir. Katılımcıların \%35,2 si üçüncü sınıf, \%33,4 ikinci sınıf ve \%31,4 ü dördüncü sınıf öğrencilerinden oluşmaktadır. Son olarak katılımcıların \%71,3’ ü lisans öğrencisi \%28,7 si ise ön lisans öğrencisidir.

Tablo 2: Frekans Analizi Sonuçları

\begin{tabular}{|c|c|c|}
\hline CINSIYET & Sıklık & Yüzde \\
\hline Kadın & 190 & 64,8 \\
\hline Erkek & 103 & 35,2 \\
\hline Toplam & 293 & 100,0 \\
\hline YAŞ & S1klık & Yüzde \\
\hline $17-20$ & 74 & 25,3 \\
\hline $21-25$ & 216 & 73,7 \\
\hline $26-29$ & 2 & ,7 \\
\hline $30-35$ & 1 &, 3 \\
\hline Toplam & 293 & $\mathbf{1 0 0 , 0}$ \\
\hline BÖLÜM & Sıklık & Yüzde \\
\hline İşletme & 76 & 25,9 \\
\hline İktisat & 23 & 7,8 \\
\hline Bankacılık ve Finans & 44 & 15,0 \\
\hline Siyaset Bilimi ve Kamu Yönetimi & 37 & 12,6 \\
\hline Uluslararası Ticaret & 32 & 10,9 \\
\hline Bankacılık ve Sigortacılık & 81 & 27,6 \\
\hline Toplam & 293 & $\mathbf{1 0 0 , 0}$ \\
\hline SINIF & Sıklık & Yüzde \\
\hline İkinci Sınıf & 98 & 33,4 \\
\hline Üçüncü Sınıf & 103 & 35,2 \\
\hline Dördüncü Sınıf & 92 & 31,4 \\
\hline Toplam & 293 & 100,0 \\
\hline EĞİTİM DÜZEYİ & Sıklık & Yüzde \\
\hline Ön lisans & 84 & 28,7 \\
\hline Lisans & 209 & 71,3 \\
\hline Toplam & 293 & 100,0 \\
\hline
\end{tabular}


İkinci adımda ise İslami bankacılığa bakış açısı ölçeğine ilişkin maddelere verilen cevapların frekanslarına bakılmıştır (Tablo 3). Tablo 3’te yer alan İslami Bakış Açısı Ölçeği sorularından ilki "İslami bankacılığı (Katılım Bankacılı̆̆ı) ne düzeyde ulaşılabilir buluyorsunuz?" sorusudur. Katılımcıların \%45,7'si soruya "kararsızım", \%28'i "ulaşılabilir", \%6,1'i ise "yeterince ulaş1labilir" şeklinde cevap vermişlerdir. "İslami bankacılıkla ilgili bilgi düzeyinizi nasıl değerlendirirsiniz?" sorusuna ise katılımcıların \%45,1'i "İslami bankacılıkla ilgili bir şeyler duydum ama ne olduğunu bilmiyorum" şeklinde \% 7,8 'i ise "İslami bankacılığı hiç duymadım" şeklinde cevap vermişlerdir. Bir diğer soru ise "İslami bankacıllğın size uygun yatırım ürünleri sunduğunu düşünüyor musunuz?" şeklindedir. Bu soruya öğrencilerin \%25,6's1 "düşünüyorum”, \%11,3' ü "düşünmüyorum” şeklinde cevap vermişlerdir. "İslami bankacılık sektöründe yatırım yapmak sizin için ne kadar önemlidir?" sorusuna \%39,9’u "kararsızım", \%29,4'ü “önemlidir" cevabını vermişlerdir. "Sizce İslami bir banka fonlarınızı ne kadar iyi yönetebilir?" sorusuna \%41 "kararsızım", \%35,5'i ise "iyi yönetebilir" cevabını vermiştir. "İslami bankacılık ve geleneksel bankacılık arasında bir tercih yapmak durumunda kalırsanız İslami bankacılığa yatırım yapmayı tercih eder misiniz" sorusuna \%34,1'i ederim, \%4,4'ü kesinlikle ederim cevabını vermişlerdir. "İslami bankacılıkla ilgili reklam veya ilanlarla karşılaşma sıklığınız nedir?" sorusuna ise \%39,2'si nadiren (ayda 1 defa), \%1,4 ü çok sık (günde 5 defa) olarak cevap vermişlerdir. "İslami bankacılığı kullanırken dini açıdan ne ölçüde zorunluluk hissedersiniz?" sorusuna \%31,4'ü zorunluluk hissetmem, \%9,2'si ise "aşırı derecede zorunluluk hissederim" cevabını vermiştir. "İslami bankacılığı finansal amaçlarım doğrultusunda düşünürüm" ifadesine öğrencilerin \%33,8'i "katılıyorum", \%16's1 ise "katılmıyorum" cevabını vermiştir. Öğrenciler "genel olarak finansal sistemde faiz esası geçerli olduğu için İslami bankacılık gerçekçi değildir" ifadesine \%23,5 oranında katılıyorum, $\% 24,2$ oranında ise katılmıyorum cevabını vermişlerdir. İslami kurallara daha uygun oldukları için "İslami bankacılığı daha fazla tercih ederim" ifadesine \%39,6'sı kararsızım, \%34,1'i "katılıyorum" ve \%14,7' si "katılmıyorum" cevabını vermiştir.

Bu sonuçlara göre öğrencilerin genel itibariyle İslami bankacılık ile ilgili bilgi düzeylerinin düşük olduğu görülmektedir. Ayrıca "ulaşılabilirlik" sorusuna verilen cevaplar ile "İ̉slami bankacılık çok geniş bir yelpazede yatırım firsatları sunmaktadır" ifadesine katılım düzeylerinden hareketle ögrencilerin İslami bankacılık farkındalık düzeylerinin orta düzeyde olduğu söylenebilir. Din faktörünün ise İslami bankacılık tercihinde yine orta düzeyde etkili bir faktör olabileceği görülmektedir. Ayrıca öğrencilerin İslami bankacılığa yönelik algılarının genel itibariyle olumlu olduğunu söyleyebiliriz.

Tablo 3: İslami Bankacılığa Bakış Açısı Ölçeği

\begin{tabular}{ccc}
\hline İslami bankacılı̆̆ı (Katılım Bankacılığı) ne düzeyde ulaşılabilir buluyorsunuz? & Sıklık & Yüzde \\
\hline Ulaşılabilir değil & 19 & 6,5 \\
Çok az ulaşılabilir & 40 & 13,7 \\
Kararsızım & 134 & 45,7 \\
Ulaşılabilir & 82 & 28,0 \\
Yeterince ulaşlabilir & 18 & 6,1 \\
\hline Toplam & $\mathbf{2 9 3}$ & $\mathbf{1 0 0 , 0}$ \\
\hline İslami bankacılıkla ilgili bilgi düzeyinizi nasıl değerlendirirsiniz? & Sıklık & Yüzde \\
\hline İslami bankacılıkla ilgili çok şey biliyorum & 43 & 14,7 \\
İslami bankacılıkla ilgili bir şeyler biliyorum & 47,0 \\
İslami bankacılıkla ilgili bir şeyler duydum ama çok azını anladım & 48 & 16,4 \\
İslami bankacılıkla ilgili bir şeyler duydum ama ne olduğunu bilmiyorum & 132 & 45,1 \\
İslami bankacılığı hiç duymadım & 23 & 7,8 \\
\hline Toplam & $\mathbf{2 9 3}$ & $\mathbf{1 0 0 , 0}$ \\
\hline İslami bankacılı̆̆ın size uygun yatırım ürünleri sunduğunu düşünüyor & Sıklık & Yüzde \\
musunuz? & 8 & 2,7 \\
\hline Kesinlikle düşünmüyorum & 33 & 11,3 \\
Düşünmüyorum & 169 & 57,7 \\
Kararsızım & 75 & 25,6 \\
Düşünüyorum & 8 & 2,7 \\
\hline
\end{tabular}




\begin{tabular}{|c|c|c|}
\hline Toplam & 293 & $\mathbf{1 0 0 , 0}$ \\
\hline $\begin{array}{l}\text { İslami bankacılıktaki katılımcılık esasının geleneksel bankacılıktan daha faydalı } \\
\text { olduğuna inanıyor musunuz? }\end{array}$ & Sıklık & Yüzde \\
\hline Kesinlikle inanmiyorum & 9 & 3,1 \\
\hline İnanmiyorum & 29 & 9,9 \\
\hline Kararsizim & 170 & 58,0 \\
\hline İnanıyorum & 71 & 24,2 \\
\hline Kesinlikle inaniyorum & 14 & 4,8 \\
\hline Toplam & 293 & 100,0 \\
\hline İslami bankacılık sektöründe yatırım yapmak sizin için ne kadar önemlidir? & Sıklık & Yüzde \\
\hline Hiç önemli değildir & 19 & 6,5 \\
\hline Ö́nemli değildir & 52 & 17,7 \\
\hline Kararsızım & 117 & 39,9 \\
\hline Önemlidir & 86 & 29,4 \\
\hline Çok önemlidir & 19 & 6,5 \\
\hline Toplam & 293 & 100,0 \\
\hline Sizce İslami bir banka sizin fonlarınızı ne kadar iyi yönetebilir? & Sıklık & Yüzde \\
\hline İyi yönetemez & 11 & 3,8 \\
\hline Biraz yönetebilir & 40 & 13,7 \\
\hline Kararsizim & 120 & 41,0 \\
\hline İyi yönetebilir & 104 & 35,5 \\
\hline Çok iyi yönetebilir & 18 & 6,1 \\
\hline Toplam & 293 & 100,0 \\
\hline $\begin{array}{l}\text { İslami bankacılık ve geleneksel bankacılık arasında bir tercih yapmak } \\
\text { durumunda kalırsanız İslami bankacılığa yatırım yapmayı tercih eder misiniz? }\end{array}$ & Sıklık & Yüzde \\
\hline Kesinlikle Ederim & 13 & 4,4 \\
\hline Ederim & 55 & 18,8 \\
\hline Kararsızım & 92 & 31,4 \\
\hline Etmem & 100 & 34,1 \\
\hline Kesinlikle Etmem & 33 & 11,3 \\
\hline Toplam & 293 & 100,0 \\
\hline İslami bankacılıkla ilgili reklam veya ilanlarla karşılaşma sıklığınız nedir? & Siklık & Yüzde \\
\hline Hiç & 90 & 30,7 \\
\hline Nadiren (ayda 1 defa) & 115 & 39,2 \\
\hline Bazen (haftada 1 defa) & 69 & 23,5 \\
\hline Sik (haftada 5 defa) & 15 & 5,1 \\
\hline Çok sık (günde 5 defa) & 4 & 1,4 \\
\hline Toplam & 293 & 100,0 \\
\hline İslami bankacılığı kullanırken dini açıdan ne ölçüde zorunluluk hissedersiniz? & Siklık & Yüzde \\
\hline Zorunluluk hissetmem & 92 & 31,4 \\
\hline Çok az zorunluluk hissederim & 34 & 11,6 \\
\hline Kismen zorunluluk hissederim & 83 & 28,3 \\
\hline Zorunluluk hissederim & 57 & 19,5 \\
\hline Aşırı derecede zorunluluk hissederim & 27 & 9,2 \\
\hline Toplam & 293 & $\mathbf{1 0 0 , 0}$ \\
\hline İslami bankacılığı finansal amaçlarım doğrultusunda düşünürüm. & Sıklık & Yüzde \\
\hline Kesinlikle Katılmıyorum & 14 & 4,8 \\
\hline Katılmiyorum & 47 & 16,0 \\
\hline Kararsizım & 110 & 37,5 \\
\hline Katıliyorum & 99 & 33,8 \\
\hline Kesinlikle Katılıyorum & 23 & 7,8 \\
\hline Toplam & 293 & 100,0 \\
\hline İslami bankacılık diğer bankaların iyi bir alternatifidir. & Sıklık & Yüzde \\
\hline Kesinlikle Katılmiyorum & 10 & 3,4 \\
\hline Katılmiyorum & 27 & 9,2 \\
\hline Kararsizım & 133 & 45,4 \\
\hline Katıliyorum & 104 & 35,5 \\
\hline Kesinlikle Katıliyorum & 19 & 6,5 \\
\hline
\end{tabular}




\begin{tabular}{|c|c|c|}
\hline Toplam & 293 & $\mathbf{1 0 0 , 0}$ \\
\hline $\begin{array}{c}\text { Genel olarak finansal sistemde faiz esası geçerli olduğu için İslami bankacılık } \\
\text { gerçekçi değildir. }\end{array}$ & Sıklık & Yüzde \\
\hline Kesinlikle Katılmiyorum & 19 & 6,5 \\
\hline Katılmiyorum & 71 & 24,2 \\
\hline Kararsızım & 113 & 38,6 \\
\hline Katılıyorum & 69 & 23,5 \\
\hline Kesinlikle Katıliyorum & 21 & 7,2 \\
\hline Toplam & 293 & $\mathbf{1 0 0 , 0}$ \\
\hline $\begin{array}{l}\text { İslami bankacılık kredi alma konusunda geleneksel bankacılıktan daha iyi } \\
\text { fursatlar sunar. }\end{array}$ & Sıklık & Yüzde \\
\hline Kesinlikle Katılmıyorum & 9 & 3,1 \\
\hline Katılmiyorum & 44 & 15,0 \\
\hline Kararsizım & 157 & 53,6 \\
\hline Katılıyorum & 69 & 23,5 \\
\hline Kesinlikle Katıliyorum & 14 & 4,8 \\
\hline Toplam & 293 & $\mathbf{1 0 0 , 0}$ \\
\hline $\begin{array}{c}\text { İslami kurallara daha uygun oldukları için İslami bankacılığı daha fazla tercih } \\
\text { ederim }\end{array}$ & Sıklık & Yüzde \\
\hline Kesinlikle Katılmıyorum & 14 & 4,8 \\
\hline Katılmiyorum & 43 & 14,7 \\
\hline Kararsızım & 116 & 39,6 \\
\hline Katıliyorum & 100 & 34,1 \\
\hline Kesinlikle Katıliyorum & 20 & 6,8 \\
\hline Toplam & 293 & $\mathbf{1 0 0 , 0}$ \\
\hline İslami bankacılık çok geniş bir yelpazede yatırım fursatları sunmaktadır. & Sıklık & Yüzde \\
\hline Kesinlikle Katılmıyorum & 12 & 4,1 \\
\hline Katılmiyorum & 40 & 13,7 \\
\hline Kararsizim & 194 & 66,2 \\
\hline Katılıyorum & 41 & 14,0 \\
\hline Kesinlikle Katıliyorum & 6 & 2,0 \\
\hline Toplam & 293 & 100,0 \\
\hline
\end{tabular}

\subsubsection{Açıklayıcı Faktör Analizi}

Verilerin faktör analizine uygunluğunun anlaşılması için KMO ve Barlett küresellik testi yapılmıştır. Analiz sonuçları Tablo 4' te görüldüğü gibidir. Tabloya göre örneklemin faktör analizine uygunluğu son derece yüksektir $(0,877)$. KMO değerinin 0,50 ' den yüksek olması yeterli kabul edilir.

Tablo 4: Kaiser-Meyer-Olkin Örnekleme Yeterliliği ve Bartlett Küresellik Test Sonuçları

\begin{tabular}{ccc}
\hline \multicolumn{2}{c}{ Kaiser-Meyer-Olkin Örnekleme Yeterliliği Ölçüsü } & Ki-Kare \\
\hline & sd & 1302,288 \\
Bartlett Küresellik Testi & Anlamllık & 105 \\
& &, 000 \\
\hline
\end{tabular}

Daha sonra ölçekte yer alan her bir madde için kısmi korelasyonlara ve KMO değerlerine bakılmıştır (Ters İmaj Korelasyon Matrisi). Bu değerlerin her madde için 0,50'den büyük olduğu görülmüş ve bu nedenle veri seti faktör analizi yapmaya uygun bulunmuştur. Daha sonra faktör analizine geçilmiş ve faktör analizi sonucunda bazı maddelerin tek başına faktör oluşturdukları bazılarının ise birden fazla faktör altında yer aldıkları tespit edilmiştir. Bu maddeler veri setinden çıkartılarak faktör analizi tekrarlanmış ve en son aşamada maddelerin iki faktör altında toplandıkları görülmüştür (Tablo 5). Bunlar "İslami Bankacılık Algısı" ve "İslami Bankacılığın Sunumu” şeklinde isimlendirilmiştir.

Tablo 5: Faktör Analizi Sonucu Oluşan Faktörler 


\begin{tabular}{|c|c|c|}
\hline & $\begin{array}{c}\text { "İslami Bankacılık } \\
\text { Algısı" Faktörüne } \\
\text { Verilen Katkı }\end{array}$ & $\begin{array}{c}\text { "İslami Bankacilı̆̆ın } \\
\text { Sunumu" Faktörüne } \\
\text { Verilen Katkı }\end{array}$ \\
\hline $\begin{array}{l}\text { İslami kurallara daha uygun oldukları için İslami bankacilığı } \\
\text { daha fazla tercih ederim }\end{array}$ & ,780 & ,008 \\
\hline $\begin{array}{c}\text { İslami bankacılık sektöründe yatırım yapmak sizin için ne } \\
\text { kadar önemlidir? }\end{array}$ & 770 & ,060 \\
\hline $\begin{array}{l}\text { İslami bankacılıktaki katılımcılık esasının geleneksel } \\
\text { bankacılıktan daha faydalı olduğuna inanıyor musunuz? }\end{array}$ & ,751 & 148 \\
\hline $\begin{array}{c}\text { İslami bankacilık ve geleneksel bankacılık arasında bir tercih } \\
\text { yapmak durumunda kalırsanız İslami bankacılığa yatırım } \\
\text { yapmayı tercih eder misiniz? }\end{array}$ & ,732 &,- 017 \\
\hline $\begin{array}{l}\text { İslami bankacılık kredi alma konusunda geleneksel } \\
\text { bankacılıktan daha iyi firsatlar sunar. }\end{array}$ & 697 & ,085 \\
\hline $\begin{array}{l}\text { Sizce İslami bir banka sizin fonlarınızı ne kadar iyi } \\
\text { yönetebilir? }\end{array}$ & 692 & 246 \\
\hline İslami bankacıllk diğer bankaların iyi bir alternatifidir. & 680 & ,057 \\
\hline $\begin{array}{l}\text { İslami bankacılık çok geniş bir yelpazede yatırım firsatları } \\
\text { sunmaktadır. }\end{array}$ & 669 & ,085 \\
\hline $\begin{array}{c}\text { İslami bankacıllğın size uygun yatırım ürünleri sunduğunu } \\
\text { düşünüyor musunuz? }\end{array}$ & ,507 & 393 \\
\hline $\begin{array}{c}\text { İslami bankacılıkla ilgili reklam veya ilanlarla karşılaşma } \\
\text { siklığınız nedir? }\end{array}$ & , 129 & ,736 \\
\hline $\begin{array}{c}\text { İslami bankacılıkla ilgili bilgi düzeyinizi nasıl } \\
\text { değerlendirirsiniz? }\end{array}$ & ,088 & ,733 \\
\hline $\begin{array}{c}\text { İslami bankacılığı (Katılım Bankacıllğı) ne düzeyde } \\
\text { ulaşılabilir buluyorsunuz? }\end{array}$ &,- 018 & ,625 \\
\hline
\end{tabular}

Daha sonra her bir faktöre ilişkin güvenirlik analizleri gerçekleştirilmiştir. Sonuçlar Tablo 6' da özetlenmiştir.

Tablo 6: Güvenirlik Analizleri Sonuçları

\begin{tabular}{ccc}
\hline Faktör & Madde Sayısı & Cronbach Alpha Değeri \\
\hline İslami Bankacılık Algısı & 9 &, 875 \\
İslami Bankacılığın Sunumu & 3 &, 527 \\
\hline
\end{tabular}

Güvenirlik analizi sonucunda ikinci faktörün (İslami Bankacılığın Sunumu) güvenilirliğinin düşük olduğu tespit edilmiş ve bu nedenle ilişkisel analizlerde ve ortalamalar arası farklılık analizlerinde sadece birinci faktör değerlendirmeye alınmıştır. Buna göre ilgili faktörün puanı 5' li likert ölçeğine katılım derecelerinin toplamı şeklinde hesaplanmıştır. Buradan hareketle tam puan $45^{\prime}$ tir. Puan arttıkça olumlu alg1, azaldıkça olumsuz algı söz konusu olmaktadır.

\subsection{4. İslami Bankacılık Algısı Faktörüne İlişkin Analizler}

Faktör ve güvenilirlik analizlerinden sonra çalışmada öncelikle "Bir Katılım Bankası (İslami Banka) ile çalışmayı düşünür müsünüz?" sorusuna verilen cevaplara göre bağımsız gruplar $t$ testi yapılmıştır. Sonuçlar grup ortalamaları arasında anlamlı bir farklılığa işaret etmektedir (sig.<0.05). Buna göre soruya evet diyenlerin algı puanı daha yüksektir (Tablo 7).

Tablo 7: Bağımsız Gruplar t testi Sonuçları

\begin{tabular}{|c|c|c|c|c|c|c|c|}
\hline & $\begin{array}{l}\text { Bir Katılım Bankası } \\
\text { (İslami Banka) ile } \\
\text { çalışmayı düşünür } \\
\text { müsünüz? }\end{array}$ & Örneklem & Ortalama & $\begin{array}{c}\text { Std. } \\
\text { Sapma }\end{array}$ & $\mathrm{t}$ & $\mathrm{df}$ & Sig. \\
\hline \multirow{2}{*}{$\begin{array}{c}\text { İslami Bankacılık } \\
\text { Alg1s1* }\end{array}$} & Evet & 216 & 29,78 & 4,886 & \multirow{2}{*}{6,267} & \multirow{2}{*}{291} & \multirow{2}{*}{,000 } \\
\hline & Hayır & 77 & 25,42 & 6,163 & & & \\
\hline
\end{tabular}


*Evet:1; Hayır:2 olacak şekilde kodlama yapılmıştır.

İkinci aşamada "Diğer ticari bankalar ile çalışmayı düşünür müsünüz?" sorusuna verilen cevaplara göre bağımsız gruplar $\mathrm{t}$ testi yapılmıştır. Sonuçlar grup ortalamalarında anlamlı bir farklılığa işaret etmektedir (sig.<0.05). Buna göre soruya hayır diyenlerin "İslami Bankacılık Alg1 Puanı" daha yüksektir (Tablo 8).

Tablo 8: Bağımsız Gruplar t testi Sonuçları

\begin{tabular}{|c|c|c|c|c|c|c|c|}
\hline & $\begin{array}{c}\text { Diğer ticari } \\
\text { bankalar ile } \\
\text { çalışmayı düsünür } \\
\text { müsünüz? }\end{array}$ & Örneklen & Drtalama & Std. Sapma & $\mathrm{t}$ & $\mathrm{df}$ & Sig. \\
\hline \multirow{2}{*}{$\begin{array}{c}\text { İslami Bankacilık } \\
\text { Algisı }\end{array}$} & Evet & 228 & 28,29 & 5,355 & \multirow{2}{*}{$-2,056$} & \multirow{2}{*}{290} & \multirow{2}{*}{, 041} \\
\hline & Hayır & 64 & 29,91 & 6,243 & & & \\
\hline
\end{tabular}

Ayrıca korelasyon ilişkilerine de bakılmış ve sonuçlar aşağıda yer alan Tablo 9'da görüldüğü ortaya çıkmıştır. Tabloya göre \%1 anlamlılık düzeyinde İslami Bankacılık algısı ile katılım bankası tercihi arasında düşük düzeyde anlamlı pozitif bir ilişki söz konusudur. \%10 anlamlılık seviyesinde ise İslami Bankacılık Algısı ile diğer ticari banka tercihi arasında düşük düzeyde anlamlı ve negatif bir ilişki söz konusudur.

Tablo 9: Korelasyon Analizi Sonuçları

\begin{tabular}{llrr}
\hline & & $\begin{array}{c}\text { Bir Katılım Bankası } \\
\text { (İslami Banka) ile } \\
\text { çalışmayı düşünür } \\
\text { müsünüz? }\end{array}$ & $\begin{array}{c}\text { Diğer ticari bankalar ile } \\
\text { çalışmayı düşünür } \\
\text { müsünüz? }\end{array}$ \\
\hline \multirow{2}{*}{ ISLAMİ BANKACILIK ALGISI } & Pearson Korelasyon Katsayısı &, 345 &,- 109 \\
& Anlamlılık &, 000 &, 061 \\
& Gözlem & 293 & 293 \\
\hline
\end{tabular}

\subsubsection{Katılım Bankacılığı Bilgi Düzeyi ile Alınan Ders Arasındaki İlişski}

Öğrencilerin aldıkları finans derslerine göre katılım bankacılı̆̆ı bilgi düzeylerinin değişip değişmediği analiz edildiğinde aşağıdaki sonuçlar (Tablo 9) ortaya çıkmıştır. Buna göre Tablo 9' de yer alan ANOVA testi sonuçlarına bakıldığında grup ortalamaları arasında anlamlı bir farklılık görülmektedir ( $p$ değeri: $0,000<0.05$ ). Dolayısıyla alınan finans dersi sayısı arttıkça öğrencilerin bilgi düzeyleri artmaktadır. Scheffe ve Tukey testleri sonuçlarında ve Tablo 9' de yer alan tanımlayıcı istatistiklere bakıldığında bu durum açık bir şekilde görülmektedir.

Tablo 10: Alınan finans dersi sayısına göre bilgi düzeyi ANOVA Analizi

\begin{tabular}{cccccc}
\hline & N & Ortalama & Std. Sapma & F & Sig. \\
\hline Bir ders aldım & 31 & 2,52 & 1,288 & & \\
İki ders aldım & 24 & 3,21 & 1,285 & & \multirow{2}{*}{0,549} \\
Üç ders aldım & 43 & 3,27 & 1,202 & & \\
Üçten daha fazla ders aldım & 195 & 3,34 & 1,158 & & \\
\hline Toplam & $\mathbf{2 9 3}$ & $\mathbf{3 , 1 5}$ & $\mathbf{1 , 2 2 2}$ & & \\
\hline
\end{tabular}

\subsubsection{Cinsiyete Göre Bağımsız Gruplar t- Testi}

Tablo 10 ve Tablo 11'de yer alan bağımsız gruplar te testi çıktılarına göre "Bir Katılım Bankası (İslami Banka) ile çalışmayı düşünür müsünüz?", "Diğer ticari bankalar ile çalışmayı düşünür müsünüz?" ve "İslami bankacılıkla ilgili bilgi düzeyinizi nasıl değerlendirirsiniz?" sorularına verilen cevaplar ile İslami bankacılık algı düzeyinin cinsiyete göre farklılık göstermedikleri görülmektedir. 
Tablo 11: Grup İstatistikleri

\begin{tabular}{ccccc}
\hline & CINSSIYET & Örneklem & Ortalama & Std. Sapma \\
\hline Bir Katılım Bankası (İslami Banka) & KADIN & 190 & 1,25 &, 436 \\
\cline { 2 - 4 } çalışmayı düşünür müsünüz? & ERKEK & 103 & 1,28 &, 452 \\
Diğer ticari bankalar ile çalışmayı düşünür & KADIN & 190 & 1,19 &, 410 \\
\cline { 2 - 4 } müsünüz? & ERKEK & 103 & 1,28 &, 452 \\
İslami bankacılıkla ilgili bilgi düzeyinizi & KADIN & 190 & 3,11 & 1,201 \\
\cline { 2 - 5 } nasıl değerlendirirsiniz? & ERKEK & 103 & 3,23 & 1,262 \\
\hline
\end{tabular}

Tablo 12: Cinsiyete Göre Bağımsız Gruplar t testi

\begin{tabular}{llll}
\hline & \multicolumn{2}{c}{ Ortalamaların eşitliği t testi } \\
\cline { 2 - 4 } & $\mathbf{t}$ & $\mathbf{d f}$ & Sig. \\
\hline $\begin{array}{l}\text { Bir Katılım Bankası (İslami Banka) ile çalışmayı düşünür } \\
\text { müsünüz? }\end{array}$ &,- 535 & 291 &, 593 \\
\hline Diğer ticari bankalar ile çalışmayı düşünür müsünüz? & $-1,668$ & 291 &, 096 \\
\hline İslami bankacılıkla ilgili bilgi düzeyinizi nasıl değerlendirirsiniz? &,- 819 & 291 &, 414 \\
\hline İslami Bankacılık Algısı & $-1,198$ & 291 &, 232 \\
\hline
\end{tabular}

\subsubsection{Din Faktörünün İslami Bankacılık Tercihine Etkisi ANOVA Analizi}

Yapılan analiz sonucunda Tablo 13'e göre "Bir Katılım Bankası (İslami Banka) ile çalışmayı düşünür müsünüz?" sorusuna verilen cevapların "İslami kurallara daha uygun oldukları için İslami bankacıllı̆ı daha fazla tercih ederim" ifadesine katılım derecesi gruplarına göre istatistiksel açıdan farklılaştığı görülmüştür ( $p$ değeri: $0,000<0,05)$.

Tablo 13: Tek Yönlü ANOVA Testi Tanımlayıcı İstatistikler

\begin{tabular}{cccccc}
\hline & Örneklem & Ortalama & Std. Sapma & F & p değgri \\
\hline Katılmıyorum & 57 & 1,47 &, 504 & & \\
Kararsızım & 116 & 1,23 &, 424 & & \multirow{2}{*}{000} \\
Kat1lyyorum & 120 & 1,19 &, 395 & & \\
Total & $\mathbf{2 9 3}$ & $\mathbf{1 , 2 6}$ & $\mathbf{4 4 1}$ & & \\
\hline
\end{tabular}

Bu farkl111k Tablo 14'te verilen Tukey testi sonuçlarından daha net anlaşılmaktadır. Buna göre ilgili soruya "kesinlikle katılmıyorum ve katılmıyorum" şeklinde cevap verenlerin ortalaması 1,47 iken "kesinlikle katıliyorum ve katıliyorum" şeklinde cevap verenlerin ortalamas1 1,19'dur. Buradan hareketle ifadesine "kesinlikle katılıyorum" ve "katılıyorum" şeklinde cevap verenlerin "Bir Katılım Bankası (İslami Banka) ile çalışmayı düşünür müsünüz?" sorusuna genellikle "Evet" dedikleri anlaşılmaktadır.

Tablo 14: Tukey Testi

\begin{tabular}{cccc}
\hline $\begin{array}{c}\text { İslami kurallara daha uygun oldukları } \\
\text { için İslami bankacilığı daha fazla } \\
\text { tercih ederim }\end{array}$ & $\begin{array}{c}\text { İslami kurallara daha uygun oldukları } \\
\text { için İslami bankacilığı daha fazla } \\
\text { tercih ederim }\end{array}$ & Std. Hata & p değeri \\
\hline Katılmıyorum & Kararsızım &, 069 &, 002 \\
& Katıllyorum &, 069 &, 000 \\
Kararsızım & Katılmıyorum &, 069 &, 002 \\
& Katıllyorum &, 056 &, 743 \\
Katılıyorum & Katılmıorum &, 069 &, 000 \\
& Kararsızım &, 056 &, 743 \\
\hline
\end{tabular}




\section{SONUÇ}

Bu çalışma, reel ve potansiyel olarak banka müșterisi, finansal sistem katılımcısı veya aktörü olarak değerlendirilebilecek üniversite öğrencilerinin katılım bankacılığı terim ve hizmetleri konusundaki bilgi, farkındalık ve algı düzeylerinin anlaşılmasını amaçlamıştır. Ayrıca öğrencilerin gelecekte katılım bankaları tercih edip etmeme eğilimleri ve katılım bankacılığı ile ilgili algı ve düşünceleri tespit edilmeye çalışılmışıı. $\mathrm{Bu}$ çalışmanın bir diğer amacı üniversite öğrencilerinin katılım bankacılığı ürün ve hizmetleri ile ilgili farkındalıklarını ve algılamalarını etkileyen demografik faktörlerin araştırılmasıdır. Çalışmada ayrıca öğrencilerin aldıkları eğitimin katılım bankacılığı ile ilgili alg1 ve bilgi düzeylerine etkisi de incelenmiştir.

Yapılan analizler sonucunda katılım bankacılığı tercihinin katılım bankacılığı algısına göre farklılaştığı görülmüş̧ür. Bununla birlikte katılım bankaları dışındaki bankalarla çalışmayı tercih eden katılımcıların katılım bankacılığı algı puanının daha düşük olduğu görülmüştür. Çalışma sonucunda, ayrıca, alınan finans dersi sayısı arttıkça öğrencilerin katılım bankacılığı ile ilgili bilgi düzeylerinin arttığı tespit edilmiştir. Çalışmanın sonuçları, literatür kısmında belirtilen Erol ve El-Bdour (1989), Erol, Kaynak ve El-Bdour (1990) tarafından yapılan çalışmalarının bulgularından biri olan din faktörünün katılım bankalarının tercihi üzerinde etkisinin olmaması bulgusu ile uyumlu olmamakla birlikte, Bley ve Kuehn (2004), Rustam, Bibi, Zeman ve Haq (2011), Navi, Yazid ve Muhammed (2013), Toraman, Ata ve Buğan (2015), Noonari vd. (2015), Özen, Şenyıldız ve Akarbulut (2016), Asdullah ve Yazdifer (2016), Ahmed, Bono ve Dawood (2017), Riaz, Khan ve Khan (2007), Anaç ve Kaya (2017) tarafından yapılan çalışmaların bulguları ile genel anlamda uyumludur.

Çalışma sonucunda, katılım bankacılığı ve ürün ve hizmetlerinin Çankırı Karatekin Üniversitesi ögrencileri arasında bilinirlik ve farkındalık düzeylerinin oldukça düşük olduğu gözlenmiştir. Buradan hareketle genç nüfusa yönelik bankacılık ürün ve hizmetlerinin pazarlanma faaliyetlerinin daha etkin bir şekilde yapılması gerektiği söylenebilir. Bu çalışma temelde iki noktada önem arz etmektedir. Bunlardan birincisi, çalışmanın, Türkiye'de potansiyel genç müşteriler bağlamında katılım bankacılığının bilinirliğini ve tercihini ve bu tercihi etkileyen faktörlerin araştırılmasını konu almasıdır. Bu özelliği ile literatürdeki bir boşluğu doldurmaktadır. Bu nedenle, bu çalışmanın bulguları gelecekteki benzer çalışmalar için başlangıç noktası oluşturabilir. Diğer yandan bu çalışma, katılım bankalarının yöneticilerinin genç müşterilerin katılım bankacılığı tercihlerini etkileyen unsurları belirlemelerine yardımcı olacak sonuçlar ortaya koymaktadır. Bu sayede daha uygun pazarlama stratejileri geliştirmeleri söz konusu olabilecektir. Ayrıca gelecekte etkin birer finansal piyasa katılımcısı olma potansiyeli taşıyan gençlerin katılım bankacılığı ile ilgili olarak daha fazla bilgilendirilmesine yönelik çalışmaların arttırılması, sektörün gelecekte daha fazla gelişmesi ve büyümesi için önemli olduğu düşünülmektedir.

\section{KAYNAKÇA}

Abdullah, A. A., Sidek, R. ve Adnan, A. A. (2012). Perception of non-Muslims customers towards Islamic banks in Malaysia. International Journal of Business and Social Science, 3(11).

Ahmad, N. ve Haron, S. (2002). Perceptions of Malaysian corporate customers towards Islamic banking products and services. International Journal of Islamic Financial Services, 3(4), 13-29.

Ahmed, J., Bano, S. ve Dawood, L. (2017). Understanding Islamic banking: The perception and thoughtfulness of customers about Islamic banking in the context of Balochistan. Journal of Islamic Banking \& Finance, 34(3).

Anaç, T. ve Kaya, F. (2017). Bireysel müşterilerin katılım bankacıllı̆ı̆ın tercih etmesini etkileyen faktörler. Bartın Üniversitesi İktisadi ve İdari Bilimler Fakültesi Dergisi, 8 (15), 145-182.

Ariff, M. (1988). Islamic banking. Asian-Pacific Economic Literature, 2(2), 48-64. 
Asdullah, M. A. ve Yazdifar, H. (2016). Evaluation of factors influencing youth towards Islamic banking in Pakistan. ICTACT Journal on Management Studies, 2(1).

Bley, J. ve Kuehn, K. (2004). Conventional versus Islamic finance: student knowledge and perception in the United Arab Emirates. International Journal of Islamic Financial Services, 5(4), 17-30.

Brown, J., D., (1997). Shiken: JALT Testing \& Evaluation SIG Newsletter, 1(1), 20-23. [ISSN 18815537]. http://jalt.org/test/bro_1.htm

DeCarlo, L. T. (1997). On the meaning and use of kurtosis. Psychological methods, 2(3), 292.

Demir, Ö. ve Atlı, Y., (2014). Katılım bankalarında internet bankacıllğı: Elazığ ili örneği. Firat Üniversitesi Sosyal Bilimler Dergisi, 24(2).

Erol, C. ve El-Bdour, R. (1989). Attitudes, behaviour, and patronage factors of bank customers towards Islamic banks. International Journal of Bank Marketing, 7(6), 31-37.

Erol, C., Kaynak, E. ve Radi, E. B. (1990). Conventional and Islamic banks: Patronage behaviour of Jordanian customers. International Journal of Bank Marketing, 8(4), 25-35.

George, D. ve Mallery, M. (2010). SPSS for Windows step by step: A simple guide and reference. 17.0 update (10a ed.). Boston: Pearson.

Harun, T. W. R., Rashid, R. A. ve Hamed, A. B. (2015). Factors influencing products' knowledge of Islamic banking employees. Journal of Islamic Studies and Culture, 3(1), 23-33.

IFSB (2017). http://www.ifsb.org/docs/IFSB\%20IFSI\%20Stability\%20Report\%202017.pdf, Erişim Tarihi:10.01.2018

Loo, M. (2010). Attitudes and perceptions towards Islamic banking among Muslims and non-Muslims in Malaysia: implications for marketing to baby boomers and x-generation. International Journal of Arts and Sciences, 3(13), 453-485.

Nawi, F. A. M., Yazid, A. S. ve Mohammed, M. O. (2013). A critical literature review for Islamic banks selection criteria in Malaysia. International Business Research, 6(6), 143.

Noonari vd. (2015), Knowledge and perception of students regarding Islamic banking: A case study of Hyderabad Sindh Pakistan. Information and Knowledge Management, 5(7).

Oğuz, A. B. (2016). Türkiye kamu, özel sermayeli mevduat ve katılım bankalarının 2005-2013 arasındaki bazı bilanço kalemlerinin karșılaştırılması. Uluslararası Yönetim İktisat ve İşletme Dergisi, 12(29), 225-241.

Özdemır, M. ve Aslan, H. (2017). Türkiye'de İslami finansın dönüşümünün ekonomi politiği, siyaset, ekonomi ve toplum araştırmaları vakfi raporu.

Özen, E., Şenyıldız, L. ve Akarbulut, K. (2016). Faizsiz bankacılık algısı: Uşak ili örneği. Journal of Accounting Finance and Auditing Studies, 2(4), 1-19.

Riaz, U., Khan, M. ve Khan, N. (2017). An Islamic banking perspective on consumers' perception in Pakistan. Qualitative Research in Financial Markets, 9(4), 337-358.

Rustam, S., Bibi, S., Zaman, K., Rustam, A. ve Haq, Z. U. (2011). Perceptions of corporate customers towards Islamic banking products and services in Pakistan. The Romanian Economic Journal, 41, 107-123. 
Tabachnick, B.G ve Fidell L.S. (2013). Using multivariate statistics (6th ed.). Boston: Pearson.

TKBB (2015). http://www.tkbb.org.tr/Documents/Yonetmelikler/TKBB-Strateji-Belgesi.pdf, Erişim Tarihi:10.01.2018

TKBB (2016). http://www.tkbb.org.tr/Documents/Yonetmelikler/Almanak_2016.pdf, Erişim Tarihi:10.01.2018

Toraman, C., Ata, H. A. ve Buğan, M. F. (2015). İslami bankacılık faaliyetlerine yönelik müşteri algıs1 üzerine bir araștırma. Gaziantep University Journal of Social Sciences, 14(4), 761-779. 